\title{
To free ourselves we must feed ourselves
}

\author{
Leah Penniman ${ }^{1}$
}

Accepted: 22 April 2020 / Published online: 11 May 2020

(c) Springer Nature B.V. 2020

We tossed our soiled shovels into the back of the pickup truck and took one last satisfied look at the backyard garden we built for Ronya Jackson and her seven children in Troy, NY. The siblings were excitedly tucking peas and spinach into the fresh earth as we headed home to nearby Soul Fire Farm to tend the crops that would be distributed to neighbors in need. Our sacred mission is to end racism and injustice in the food system, which we do by getting land, gardens, training, and fresh food to BIPOC (Black, Indigenous, and people of color), including refugees and immigrants, survivors of mass incarceration, and others impacted by state violence.

As Mama Fannie Lou Hamer said, "When you have 400 quarts of greens and gumbo soup canned for the winter, no one can push you around or tell you what to say or do." Before, during, and after the outbreak, food apartheid disproportionately impacts (BIPOC) communities who also face higher vulnerability to COVID-19 due to factors like shared housing, lack of access to health care, environmental racism, job layoffs, immigration status, employment in the wage economy without worker protections, and more. This pandemic is exacerbating existing challenges and lays bare the cracks in the system that prevent many of us from having anything canned up for this metaphorical winter. Our society is called to account. Is now finally the time when we will catalyze the 5 major shifts needed to bring about a just and sustainable food system?

\section{Land redistribution}

As a result of colonial genocide, land grabbing, USDA discrimination, state-level nativism, lynching, and expulsion, over $98 \%$ of the farmland in this county is owned by white

This article is part of the Topical Collection: Agriculture, Food \& Covid-19.

Leah Penniman

leah@soulfirefarm.org

1 Soul Fire Farm, Grafton, NY, USA
Americans today. Ralph Paige of the Federation of Southern Cooperatives put it simply, "Land is the only real wealth in this country and if we don't own any we'll be out of the picture." We need a nationwide commitment to share the land back, so that all communities can have the means of production for food security.

\section{Justice for farm workers}

The government has designated our work, but not our lives, as "essential" in light of COVID-19. Farmworkers are excluded from many protections under the National Labor Relations Act (NLRA) and Fair Labor Standards Act (FLSA) such as collective bargaining rights, overtime limits, child labor restrictions, and workers compensation insurance. Over $3 / 4$ of those whose hands pull our food from the earth are "foreign-born" and subject to the myriad oppressions of our immigration system. We need full protection for farm workers under the law as well as pathways for laborers to become decision-makers and owners on the land where they toil.

\section{Localized mutual aid}

In West African traditional societies, we have an institution called "dokpwe" or "konbit," which refers to collective work and mutual aid. We come together to plant one another's crops, build one another's homes, share provisions, and take care of the upkeep of our commons. As conventional systems for meeting our basic needs are strained, we see communities clamoring to create "mutual aid pods" and otherwise emulate our indigenous ways of caring for all members of society. Konbit is a structure that will serve us beyond this moment of crisis. 


\section{Ecological humility}

The clergy at Otura Tukaa Temple, CA, where traditional Yoruba religion is practiced, consulted the Divine Forces to understand what it is we need to learn from this pandemic. The message is that humans have forgotten our humble place as the younger siblings of the plants and animals on earth. We have become arrogant and imagined ourselves as supreme and central. One part of the sacred verse chanted at services, was "The Heavens are weeping. Humans mistook it for rain." Our indigenous religions teach ecological humility, a way of being essential for our species survival.

\section{Universal food access with dignity}

BIPOC communities have a rich history of providing food for our families and one another in a dignified manner. Long before and after Victory Gardens, people of color were growing food through provision and community gardens. Organizations like the Black Panther Party fed over 20,000 children free breakfast every day, which became a model for school meal programs in the U.S. Food hubs, community supported agriculture (CSA), and cooperatives all have roots in Black farming communities. Rather than relying on profit-driven corporations to run the food system, we need to strengthen the food distribution models championed by those most impacted by food insecurity.

This nation has relied upon the labor, expertise, and resources of BIPOC communities to undergird the food system since its inception. Even today, without the labor of people of color, food production would screech to a halt. We are essential, not just our labor, but our lives. We hope that this becomes a moment of awakening to the truth that "to free ourselves, we must feed ourselves." All of us deserve this freedom.

Publisher's Note Springer Nature remains neutral with regard to jurisdictional claims in published maps and institutional affiliations. 